\title{
Current Issues and Challenges in the Use of Aerosolized Surfactant for Respiratory Distress Syndrome in the Newborns
}

\author{
Dion Darius Samsudin ${ }^{1, *}$ \\ ${ }^{1}$ Tambak Mother and Child Hospital, Jl. Tambak No.18, Menteng, Jakarta, Indonesia \\ *Corresponding author. E-mail: diondarius@gmail.com
}

\section{Abstract}

B ACKGROUND: Surfactant replacement therapy is a recognized treatment for respiratory distress syndrome (RDS) in the newborns. Over the past 30 years, human and animal trials have been performed regarding administration of aerosolized surfactant to the injured lung, however the result has been unsatisfactory when compared with instilled surfactant delivery via endotracheal tube (ETT). This review aims to investigate the current issues, challenges and future recommendation of aerosolized surfactant therapy.

CONTENT: Five randomized clinical trials in humans and 13 animal trials met the inclusion criteria and were reviewed. Most animal trials agree that this method of treatment is feasible. However, human trials presented conflicting results, and generally showed it to be ineffective. When compared with surfactant delivery via ETT, aerosolized surfactant is less effective in improving respiratory function.

SUMMARY: The current data from human trials does not support the implementation of aerosolized surfactant therapy to treat newborns with RDS. Further research is necessary to improve nebulization, delivery, distribution and deposition in the lung, to investigate aerosolized surfactant delivery via ETT and to determine the appropriate dose.

KEYWORDS: surfactant, aerosol, prematurity, respiratory distress syndrome

Indones Biomed J. 2013; 5(2): 91-100

\section{Abstrak}

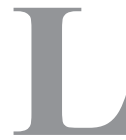

ATAR BELAKANG: Terapi pemberian surfaktan adalah terapi yang sudah diakui untuk terapi sindrom distres pernapasan (SDP) pada bayi baru lahir. Selama lebih dari 30 tahun yang lalu, penelitian pemberian surfaktan secara aerosol telah dilakukan pada manusia dan hewan untuk mengobati kondisi paru, namun menunjukkan hasil yang kurang efektif bila dibandingkan dengan pemberian bolus surfaktan melalui endotracheal tube (ETT). Ulasan ini bertujuan untuk menyelidiki perkembangan terkini, tantangan, dan rekomendasi untuk terapi surfaktan secara aerosol di masa mendatang.

ISI: Lima randomized clinical trials pada manusia dan 13 percobaan pada binatang memenuhi kriteria inklusi dan dikaji. Mayoritas percobaan pada binatang menunjukkan bahwa terapi ini memungkinkan, namun penelitian pada manusia memberikan hasil yang bervariasi, sebagian besar menunjukkan bahwa terapi ini tidak efektif. Pemberian surfaktan secara aeorosol kurang efektif jika dibandingkan dengan pemberian melalui (ETT), untuk memperbaiki fungsi paru.

RINGKASAN: Data terkini dari percobaan manusia tidak mendukung terapi pemberian surfaktan secara aerosol pada bayi dengan SDP. Penelitian lebih lanjut dibutuhkan untuk memperbaiki proses nebulisasi, pengiriman, distribusi serta deposisi partikel surfaktan di paru, menyelidiki pemberian surfaktan aerosol dengan memakai ETT, dan mencari dosis yang optimal.

KATA KUNCI: surfaktan, aerosol, prematuritas, sindrom distres pernapasan 


\section{Introduction}

Surfactant is a compound made from phospholipids in the alveoli of mammalian lungs.(1) Inside the lung, surface tension forces tend to cause alveoli to collapse. Laplace described the magnitude of the pressure $(\mathrm{P})$ exerted at the wall of alveoli, as twice the surface tension (st) divided by the radius (r) of the curvature of the surface $(\mathrm{P}=2 \mathrm{st} / \mathrm{r})$. (2) Surfactant is produced by type 2 pneumocytes lining the alveoli.(3) Its function is to reduce surface tension, which provides alveolar stability, decreases opening pressure and increases lung compliance. It also enhances alveolar fluid clearance, decreases precapillary tone, and plays a protective role for the epithelial cell surface.(4,5) Deficiency in surfactant production or function in the newborn is termed respiratory distress syndrome (RDS)(6), and are more common in preterm newborns.

The incidence of preterm birth (defined as delivery before 37 weeks of gestation)(7) in the United States of America is approximately $12-13 \%$ and $5-9 \%$ in other developed countries.(8) In Indonesia, the incidence of preterm birth varies from $9-14 \%$, depending on the region. $(9,10)$ In general, there has been an increasing trend in preterm birth worldwide over the past decades. Prematurity is the single most common cause of $\operatorname{RDS}(11,12)$, the most common lung disease in preterm infants $(6,13,14)$. The underdeveloped lung in the premature infant is characterized by insufficient alveolarisation, reduced functional surface area, widened distance between the alveolus and its adjacent capillary, deposition of fibrin into the air spaces, and pulmonary arteriolar muscularisation.(15) These structural abnormalities, combined with surfactant deficiency(16), cause alveolar instability and a tendency to collapse (atelectasis)(17), as well as capillary leak edema(16) and hyaline membrane formation.(6) These abnormalities lead to decreased pulmonary compliance, an increase in pulmonary morbidity, respiratory failure and ultimately death.

Avery and Mead first discovered the relationship between surfactant deficiency and RDS in 1959. They reported that the surface active material recovered from the lungs of infants who died due to hyaline membrane disease (now known as RDS) was largely reduced in quantity.(18) RDS commonly affects babies born from 24 to 36 weeks of gestation.(19) After 24 weeks the terminal stage of lung development occurs: proliferation of the pulmonary vascular bed, formation of respiratory structures such as alveolar ducts and alveoli, and fusion of the gas exchange epithelium to the capillary epithelium.(19) Before this period, the fetal lungs are unable to provide any gas exchange. This explains the current threshold for viability of 24-25 weeks gestational age.(20) In addition, type 2 pneumocytes do not appear before 32 to 34 weeks of gestation.(4) Therefore, these newborns will lack the ability to produce functional surfactant.

Since the relationship between surfactant deficiency and RDS was established(18,21), research has focused on the development of surfactant, and method of delivery. In 1980, Fujiwara, et al.(22) achieved the first success in treating RDS using instilled surfactant. They treated 10 preterm infants of gestational age (GA) $30.2 \pm 0.6$ weeks (mean \pm standard deviation (SD)); birth weight (BW) 1,552 $\pm 104 \mathrm{~g}$ (mean $\pm \mathrm{SD}$ ) diagnosed with RDS. The surfactant used was an organic solvent extract of bovine lung delivered endotracheally. After surfactant administration there was improvement in oxygenation, alveolar-arterial oxygen $\left((\mathrm{A}-\mathrm{a}) \mathrm{O}_{2}\right)$ gradients and systemic hypotension and reversal of acidosis. After this success, much research addressed this new method of treatment(23-29) and now surfactant delivered endotracheally has become a standard treatment for the newborn with $\operatorname{RDS}(4,13,30)$.

\section{Instillation vs. aerosolization method of surfactant delivery}

The current method of surfactant delivery via endotracheal tube (ETT)(31-33) is associated with several adverse effects. Firstly, insertion of the ETT may cause mechanical injury to the dental lamina and larynx. Secondly, protrusion of the tip of the catheter risks injury to the trachea and bronchopulmonary infections. Thirdly, introduction of large volumes of liquid into an injured lung potentially causes harm(34) (e.g. bradycardia, hypoxia, increased $\mathrm{pCO}_{2}$, pulmonary hemorrhage, fluctuations in blood pressure) $(35,36)$. Fourthly, the fluid bolus effect may occur (the uneven distribution of surfactant as it makes its way through the airways).(37) These limitations generated research into the presumed gentler method of delivering surfactant via aerosol and continuous positive airway pressure (CPAP). (38)

The endotracheal delivery of surfactant in the newborn is performed by inserting a catheter into the ETT which lies above the infant's carina. $(39,40)$ Liquid surfactant is then injected through the catheter. The alternative method, aerosolized surfactant replacement therapy (SRT), utilizes undiluted surfactant(41) or surfactant diluted with sterile water $(42,43)$, and aerosolizes it using a jet or ultrasonic nebulizer. The jet nebulizer (also known as small volume nebulizer (SVN))(44) creates an aerosol by delivering high pressure gas (air or oxygen) through the liquid surfactant and letting it flow through a narrow opening. The larger 
particles break apart creating small, aerosolized particles. (44) Ultrasonic nebulizers, on the other hand, use a highfrequency sound wave to morph liquid into a fine mist (piezoelectric principle)(44), with the droplet size being determined by the frequency of the sound waves. The aerosolized surfactant product from either nebulizer is administered with CPAP via a bridging tube such as a $\mathrm{T}$ piece $(41,45)$ (Figure 1) or modified connector $(42,46)$, which is connected to a nasally inserted airway tube positioned just behind the soft palate(18-20,23).

CPAP flow varies from $1 \mathrm{~L} /$ minute $(41)$ to $8 \mathrm{~L} /$ minute(43). The time required for treatment ranges from 20 minutes(41) to 6 hours(42), depending on the amount of surfactant delivered, the type of nebulizer, and the CPAP flow.

\section{Methods}

Three databases: Web of Science (ISI), MEDLINE (ISI) and PubMed were searched for clinical trials which involved aerosolized SRT in human and animals. The keywords used were: surfactant replacement therapy, aerosolized surfactant replacement therapy, respiratory distress syndrome and premature/preterm infants. The search returned 65 results from Web of Science (ISI), 58 results from Medline (ISI), and 95 results from PubMed. Inclusion and exclusion criteria used were:

\section{Human clinical trials}

Inclusion criteria:

1. Controlled or uncontrolled randomized clinical trial
(RCT) which involved newborn participants with RDS.

2. Aerosolized surfactant as the intervention.

3. Written in English.

Exclusion criteria:

1. Trials which recruited adult patients.

2. Infants with pulmonary disease other than RDS.

\section{Animal trials}

Inclusion criteria:

1. Trials in any species of animal that is subjected to RDS.

2. Aerosolized surfactant was utilized for treatment.

3. Written in English.

Exclusion criteria:

1. Animals with a pulmonary disease model beside RDS.

No year limit was given for both human and animal trials. Journal abstracts were screened for relevancy. If any article was found to be relevant, the full text for that article was retrieved. The reference list from relevant articles was searched manually.

Five randomized clinical trials in humans and 13 animal trials met the inclusion criteria and were included in this review.

\section{Results}

\section{Aerosolized SRT trials in newborns with RDS}

To date, there have been five human trials of aerosolized surfactant in newborns with RDS. Jorch, et al.(41) conducted an uncontrolled multicenter pilot study from five neonatal departments in Germany, which involved 20

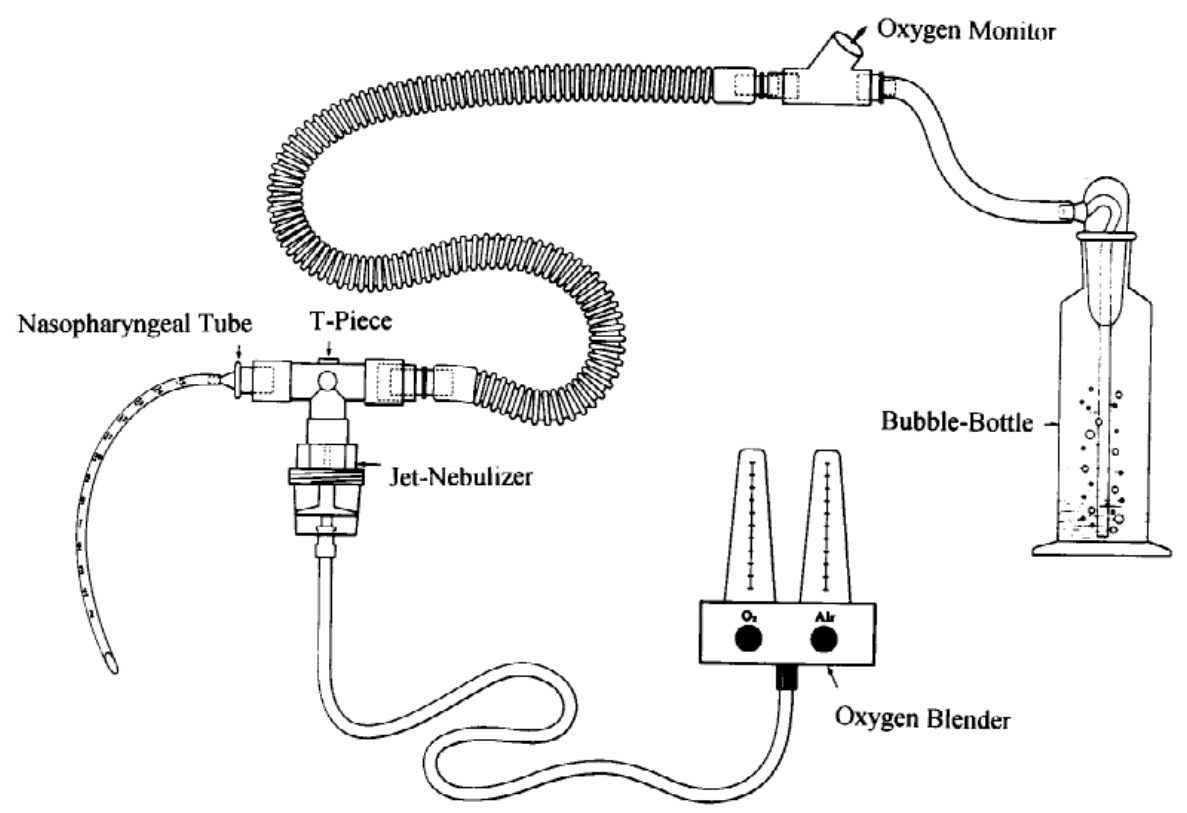

Figure 1. CPAP system used for aerosolization of surfactant.(41) (Adapted with permission from John Wiley \& Sons Ltd.) 
low birth weight (LBW) premature infants (median BW $1,680 \mathrm{~g}$, range 1,150-2,500g; median GA 31 weeks, range 28-35 weeks) diagnosed with RDS. The study used 150 $\mathrm{mg} / \mathrm{kg}$ of undiluted natural bovine surfactant (Alveofact, Lyomark Pharma GmbH, Oberhaching, Germany). The authors reported a decrease in $(\mathrm{A}-\mathrm{a}) \mathrm{O}_{2}$ gradient, improved Silverman scores, an objective measurement of respiratory distress severity assessing the degree of chest retraction, xyphoid retraction, nasal dilatation, and grunt(47), and reduction in $\mathrm{PaCO}_{2}$ (Table 1). These improvements were sustained for up to 12 hours post treatment. However, six infants had to be intubated and mechanically ventilated and their responses were considered to be short lasting. In the good responders, the effect was permanent and the only adverse reaction found was increased pulmonary secretion during administration. No information was given about the baseline difference between these two groups, or any reason for failure in the short lasting group.

Berggren, et al.(46) performed a similar trial in 32 newborns from six Swedish neonatal units. In this trial, 16 patients were randomized to a treatment group (CPAP combined with aerosolized surfactant (Curosurf, Cornerstone Therapeutics, Cary, NC) and 16 to a control group (CPAP only). Median BW and GA for both groups were similar. Despite a similar preparation method and nebulization process of the aerosolized surfactant, this trial did not show any beneficial effect of aerosolized SRT (Figure 2).

Arroe, et al.(42) performed a trial using aerosolized surfactant (Exosurf, GlaxoSmithKline, London, UK) delivered by nasal CPAP (nCPAP). This uncontrolled trial involved 22 infants, (median BW 1,525g, range 520-2,721; median GA 31 weeks, range 23-36 weeks). The objective was to assess the improvement in oxygenation with different

Table 1. Result of effects of nasopharyngeal surfactant aerosolization on respiratory parameters of infants with the respiratory distress syndrome on CPAP.(41) (Adapted with permission from John Wiley \& Sons Ltd.)

\begin{tabular}{lcccc}
\hline & $\begin{array}{c}\text { Respiratory Rate } \\
\text { (per minute) }\end{array}$ & $\mathrm{PaCO}_{2}(\mathrm{mmHg})$ & Silverman Score & $\begin{array}{c}(\mathrm{A}-\mathrm{a}) \mathrm{O}_{2} \text { gradient } \\
(\mathrm{mmHg})\end{array}$ \\
\hline Before CPAP & $56 \pm 20$ & $53 \pm 16$ & $5.9 \pm 1.4$ & $181 \pm 101$ \\
Before Nebulization & $65 \pm 18$ & $52 \pm 9$ & $5.7 \pm 1.3$ & $163 \pm 83$ \\
After $150 \mathrm{mg} / \mathrm{kg}$ & $56 \pm 14$ & $49 \pm 9$ & $4.6 \pm 1.6$ & $101 \pm 73$ \\
After 300 $\mathrm{mg} / \mathrm{kg}$ & $60 \pm 15$ & $51 \pm 9$ & $4.2 \pm 1.8$ & $121 \pm 83$ \\
30 minutes after & $55 \pm 18$ & $48 \pm 8^{*}$ & $3.5 \pm 1.9^{*}$ & $117 \pm 82^{*}$ \\
2 hours after & $62 \pm 16$ & $47 \pm 8$ & $3.3 \pm 1.9$ & $128 \pm 90$ \\
4 hours after & $63 \pm 13$ & $47 \pm 9$ & $3.5 \pm 2.1$ & $124 \pm 99$ \\
12 hours after & $58 \pm 13$ & $46 \pm 10$ & $2.4 \pm 1.7$ & $107 \pm 66$ \\
\hline
\end{tabular}

Data above are presented as means $\pm \mathrm{SD}$, *statistically significant improvement

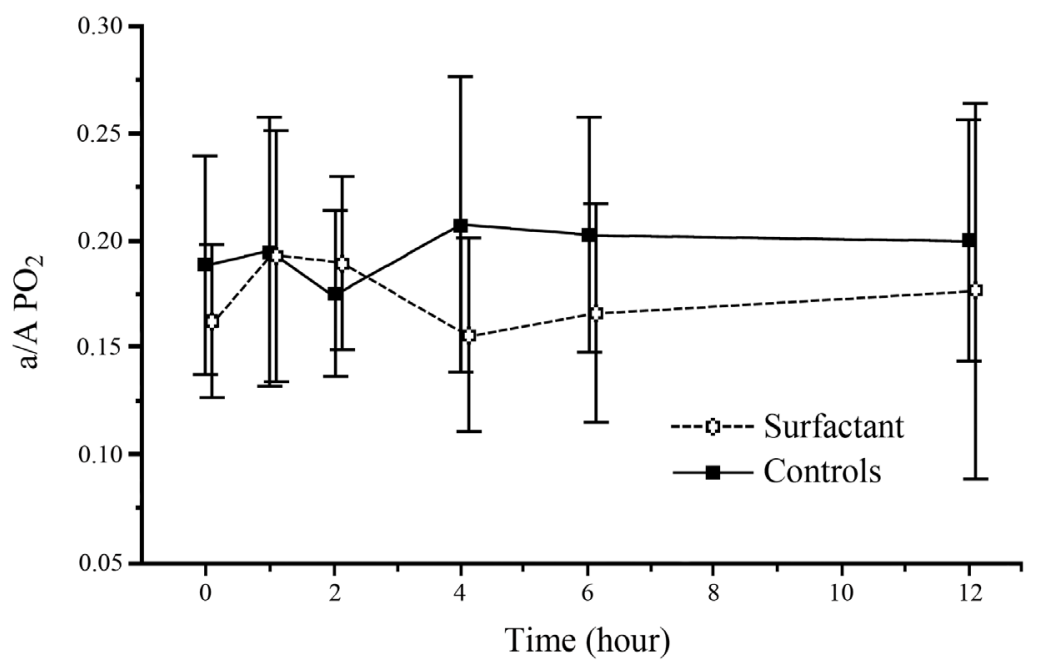

Figure 2. a/A PO2 in newborns with RDS treated with nebulized surfactant and in controls (Mean \pm SD).(46) (Adapted with permission from John Wiley \& Sons Ltd.) 
dosages of surfactant. Infants with mild to moderate RDS (a/A ratios $>0.2)$ and no sign of infection, severe asphyxia, or congenital malformations were included. They were randomly assigned into four groups receiving either 2, 4, 5, or 8 vials of Exosurf in two divided doses six hours apart. There was no significant relationship between changes in a/A ratio, dose of Exosurf, or gestational age. During the trial, 8 infants had to be intubated and mechanically ventilated. Two infants were intubated before the dose was completed due to pneumothoraces. Six others were intubated two hours after the treatment. Four of these were treated with additional instilled surfactant afterwards, however, only one infant showed improvement. The authors doubted whether surfactant administration was universally necessary in this group of preterm infants.

In 2006, Finer, et al.(43) performed a trial which involved 17 neonates from four hospitals in the United States. Six infants were between 28-29 weeks GA, and 11 infants were between 30-32 weeks GA. BW ranged from 1,033 to 2,296 grams. The infants were given aerosolized Aerosurf via CPAP in the first 30 minutes of life. A low flow of $1 \mathrm{~L} /$ minute was used.(41,46) Infants were randomized into two clusters: (1) three hours of treatment and a three hours break, repeated up to four times, and (2) three hours of treatment and a one hour break, repeated up to four times. No group served as a control. Eleven infants were successfully treated using a single dose of surfactant. All of the infants survived, however six required intubation and instilled surfactant administration. Of the 17 infants, four developed RDS at 24 hours, seven needed intermittent mechanical ventilation and two developed bronchopulmonary dysplasia at 28 days. Overall, the procedure was safe and did not show any side effects. Four years later, Finer, et al.(48) performed another trial involving 17 preterm infants at risk for RDS, using a novel vibrating membrane nebulizer Aeroneb Pro (Aerogen Ltd., Dangan, Ireland) to aerosolize $20 \mathrm{mg} / \mathrm{mL}$ of Aerosurf for three hours (volume of 15-54 mL), with retreatment separated by at least 1 or 3 hours. All infants survived, however 5 infants required additional endotracheal surfactant administration, 4 infants were diagnosed with RDS at 24 hours, and the mean $\mathrm{FiO}_{2}$ was 0.4 at baseline, and 0.32 at 4 hours post treatment.

\section{Animal trials of aerosolized surfactant}

Numbers of experiments have been performed in different species of animals: rats(49-53), rabbits(54-56), lambs(57,58), and sheep(59-61) to test the feasibility of and response to aerosolized SRT in RDS. RDS in these animals was generated by methods including bronchoalveolar lavage (BAL) using saline solution(51,53,54,56,59-61),
Escherichia coli endotoxin suspension injection(49,52), aspiration of acidified milk(50), and forced preterm delivery $(55,57,58)$. In all animal trials, the animals were anaesthetized before one of the lung deterioration procedures was performed (except RDS caused by forced preterm delivery). Baseline values were recorded (e.g. $\mathrm{PaO}_{2}$ ), aerosolized surfactant was administered, and changes in lung function were measured over a designated period of time. The baseline $\mathrm{PaO}_{2}$ in each animal trial ranged from $<10 \mathrm{kPa}(50)$, to $25 \mathrm{kPa}(49)$, mimicking RDS. Aerosolized surfactant was delivered from either a jet(51, $54)$ or an ultrasonic nebulizer(49,50,52,53,55,57,58,61). The types of surfactant used were modified natural surfactant (MNS) from bronchoalveolar lavage fluid of animals $(49,50,52,53,55,57,58)$, Curosurf(51), Survanta (AbbVie Inc., North Chicago, IL) $(54,57,59,60)$, Exosurf(54), or Alveofact(56) The ventilator settings in each trial were kept constant throughout.

Lewis, et al.(57) performed a study to compare the efficacy of aerosolized MNS, aerosolized Survanta and endotracheal MNS in the treatment of preterm lambs. The aerosolized MNS and aerosolized Survanta groups had a significant increase in ventilation efficiency index and dynamic compliance. In addition, both groups achieved pressure-volume curves that were comparable to the instilled MNS group. Two years later, Lewis, et al. conducted a comparison of aerosolized versus instilled Survanta to salinelavaged adult sheep.(61) After an aerosolization period of 3 hours with a dose of $\sim 8 \mathrm{mg} / \mathrm{kg}$ of surfactant, animals in the aerosolized surfactant group had significant increases in $\mathrm{PaO}_{2}$ at 150 and 180 minutes $(p<0.01)$, and significant decreases in $(\mathrm{A}-\mathrm{a}) \mathrm{O}_{2}$ gradient at $120-180$ minutes $(p<0.05)$. Those improvements were slower compared to the instilled surfactant group who showed significant $\mathrm{PaO}_{2}$ increases at $120(p<0.05), 150$ and 180 minutes $(p<0.01)$, while the (A-a) $\mathrm{O}_{2}$ gradient decreased at $90(p<0.05)$ and $120-180$ minutes $(p<0.01)$. In addition, at the endpoint of the study (180 minutes), the instilled surfactant group showed significantly higher $\mathrm{PaO}_{2}$ values $(p<0.05)$, and lower $(\mathrm{A}-\mathrm{a}) \mathrm{O}_{2}$ gradients $(p<0.05)$ compared to the aerosolized group.

A trial using sheep born prematurely was performed by Henry, et al.(58) Initial assessment of lung function was performed at 15 minutes of age, and the sheep were grouped into two categories: low and moderate compliance. Subsequently, the sheep were randomized into three treatment groups: aerosolized surfactant only, instilled surfactant followed by aerosolized surfactant, and instilled surfactant followed by another instilled dose, and a control group. The instilled followed by aerosolized group showed that the deposition of aerosolized surfactant followed the 
distribution pattern of the previously instilled surfactant. The aerosolized only group however, did not show uniform distribution, and very small clinical effect. They concluded that the distribution of aerosolized surfactant was related to the degree of lung maturation (the moderate compliance group showed better distribution), and the pattern of lung injury (less effective in a non-uniform pattern of lung injury).

Lewis, et al. $(59,60)$ carried out two trials in adult sheep with a non-uniform lung injury pattern, generated by isolating parts of the lung from the saline lung lavage procedure. These trials found that the aerosolized surfactant was preferentially deposited in the healthy region of the lung and very little in the injured part, which therefore reduced the overall effect. The group treated with instilled surfactant showed that liquid surfactant is able to penetrate to the unhealthy region of the lung, resulting in more deposition in the injured part of the lung and greater improvement in lung function parameters.

Trials of aerosolized surfactant using rat models (49,51-53) used instilled surfactant as a comparison. Bahlamann, et al.(51) found that the effect of aerosolized surfactant differed between individual animals treated, from very little response to an improvement comparable with instilled surfactant treatment. However, the response was slower than that of instilled surfactant. This result is in concordance with the studies by Tashiro, et al.(49) and Dijk, et al.(56) who additionally reported that aerosolized surfactant administration did not cause significant changes in mean arterial blood pressure (MABP). In contrast, animals in the instilled group experienced a decrease in MABP of $25-30 \%(49,56)$ and a more severe decrease in cerebral blood flow(56). There was no difference in pulmonary blood flow between aerosolized or instilled surfactant groups.(56) In these 3 experiments, the therapeutic effect of instilled surfactant was still superior to aerosolized surfactant. The most recent trial by Tashiro, et al.(52) found that sustained amelioration in $\mathrm{PaO}_{2}$ was related to the duration of aerosolization (the group receiving aerosolization for up to 120 minutes had better $\mathrm{PaO}_{2}$ value at 180 minutes compared to the groups receiving aerosolization for 30 and 60 minutes).

Cui, et al.(50) combined aerosolized surfactant and aerosolized dextran in treating acute RDS caused by acidified milk in rats. In the surfactant only and surfactant plus dextran group, the $\mathrm{PaO}_{2}$ improved from $<13$ to $>50 \mathrm{kPa}$ after 30 minutes of treatment. However, the surfactant only group showed a gradual decline in $\mathrm{PaO}_{2}$ to $<17 \mathrm{kPa}$ at 180 minutes, whereas it remained $>38 \mathrm{kPa}$ at 180 minutes in the surfactant plus dextran group.
Fok, et al.(54) compared the effectiveness of aerosolized Exosurf and Survanta generated by either a jet or ultrasonic nebulizer in rabbits. They found that the group treated with Exosurf via jet nebulizer achieved the highest deposition of surfactant in the lung. The clinical effect, however, was limited and did not show significant benefit in treating RDS.

Ellyett, et al.(55) administered dried surfactant to rabbits delivered prematurely at 27 days (normal gestation 31 days). The surfactant preparation was generated by suspending surfactant in a sodium chloride solution, nebulizing and then drying it with radiant heat. This produces smaller particles with better ability to travel the upper airways. The dried aerosolized surfactant group had improved survival $(67 \%)$, compared with the undried aerosolized surfactant (45\%) or control (24\%) groups.

\section{Types of nebulizers and their challenges}

Differences are noted between jet and ultrasonic nebulizers. Jet nebulizers have the advantage of using simple, tidal breathing, and are better for aerosolizing drug mixtures. However, the treatment time is longer.(62) Ultrasonic nebulizers, on the other hand, produce a higher rate of output that can deliver surfactant faster, but with larger particles generated. $(63,64)$ Drug concentration in the reservoir might increase with jet nebulizers (because of evaporation and recirculation), whereas it is more constant with ultrasonic nebulizers. $(62,65)$ Jet nebulizers can be combined with low inspiratory flows and volume, therefore are more commonly used to nebulize drugs in newborns below two months of age (who have low flows and volume).(44,66) Finally, and most importantly, ultrasonic nebulizers generate energy that is dissipated as heat. Heat-sensitive proteins in the surfactant solution might therefore be denatured.(44) Despite these differences, there does not seem to be any correlation between the type of nebulizer and the outcome. More trials were performed with ultrasonic nebulizers than with jet nebulizers $(6,11)$, however, all the trials in humans were performed using jet nebulizers.

\section{Aerosolized surfactant particle diameter and activity}

The mean diameter of aerosol particles in human trials (measured with low-angle scattering technique)(41,46) is generally $<4 \mu \mathrm{m}$, which is considered ideal for deposition in central and terminal airways and alveoli(44,67).The aerosol product was highly effective in reducing surface tension when tested by a Wilhelmy-Langmuir balance (aerosolized surfactant is spread at the air-water interface and compressed by a teflon barrier. Reduction in attractive force as shown by the force transducer indicates low surface tension)(46) 
Ellyett, et al.(55) postulated that smaller particles will have maximum penetration but poor deposition and large particles poor penetration but good deposition in the lung. However, research has shown that even a mean diameter of $4 \mu \mathrm{m}$ produced a good response(41), whereas a much smaller particle (mean diameter $0.74 \mu \mathrm{m}$ ) did not show any improvement in lung function(54). When compared with instilled surfactant, aerosolized surfactant takes a longer time to initiate treatment effect, and the lung improvement is not as effective as instilled surfactant.(50)

Another point to consider is the change of environment from the nebulizer to the lung and its effect on the particle size. Inside the nebulizer device, aerosol is produced under relatively dry ambient conditions. Once in the airway, the temperature and humidity increase, and due to the hygroscopic (water absorbing molecule) nature of the aerosolized surfactant, the particle will grow in size.(44)

\section{Types of surfactant used}

The 17 trials in humans and animals use different surfactant preparations (e.g. Alveofact, Curosurf, Survanta and Exosurf).(68) The therapeutic effect of the same type of surfactant cannot be compared because there were not enough trials utilizing the same type of surfactant. However, most trials used natural surfactant derived from lung lavage fluid of animals (nine trials), including the study in humans that was shown to be successful by Jorch, et al. $(18,26,33,34$, 36-40) Regarding the types of surfactant used, the lung improvements were inconsistent in human trials, and did not show any relation with overall mortality in human newborn trials.

\section{Distribution and deposition of surfactant in the lung and the nebulizer equipment}

Pulmonary deposition of aerosolized surfactant could not be assessed in human trials as biopsy is needed to accurately determine deposition. Surfactant deposition in animal lungs ranged from $0.4 \%$ in adult rats(51) to $25 \%$ in preterm sheep(58). Surprisingly, even the lowest average pulmonary deposition of $0.46 \%$ is associated with significant improvement in lung function.(51) As for distribution, two animal trials in lambs(57) and sheep(61) found that aerosolized surfactant was distributed more evenly compared with instilled surfactant in a uniform pattern of lung injury.

Jorch, et al.(41) estimated that only $10 \%$ of nebulized surfactant will enter the nCPAP tube. Given the total amount of surfactant used (345 to $750 \mathrm{mg}$ ), clinical improvement is thus due to approximately 35 to $75 \mathrm{mg}$ of surfactant (per subject).(41) This is a major dose effective advantage of aerosolized surfactant, compared with the higher standard dose used in the instillation method for newborns.(47) However, a higher dose to be aerosolized is still required in the first place. Fuller, et al.(69) investigated the nebulization of radiolabelled saline delivered via ETT and found that $50 \%$ of the total saline was deposited into a target chamber (which was designed to represent the lung).

Surfactant labelled with radioactive technetium-99m pertechnetate $(25,36,40)$ or $\left[{ }^{3} \mathrm{H}\right]$ choline $(57)$ was used to assess the distribution pattern in the lung and the nebulizer or respiratory circuit. Ten percent(57) to $60 \%(49)$ of the total radioactivity (thus the surfactant) was found in the nebulization circuit and filter, $\mathrm{T}$ piece, expiratory tubing, carina, and trachea. Li, et al.(53) washed the expiratory tubing, nebulization filter and circuit to determine the phospholipid content. They found that $35-45 \%$ of the aerosolized surfactant was found in the filter of the nebulizer circuit, and $50-60 \%$ in the expiratory tubing as condensed liquid.(53) Apart from the surfactant that is deposited in the lung, the remaining surfactant was not found and was suggested to have escaped into the ambient air via the filter(49), or lost during expiration(41).

Fok, et al.(54) suspected that surfactant which had condensed inside the ventilator tubing might be transferred into the lung during the ongoing ventilation process, causing further deposition of surfactant and clinical improvement. To investigate this theory, the ventilator tubing was positioned at a higher level than the animals. This produced significantly higher lung deposition of surfactant, and improvement in lung condition, than when ventilator tubing was positioned lower. Henry, et al.(58) applied a modified nebulizer which allowed aerosolized surfactant to be delivered only during inspiration, thus utilizing less surfactant materials. Therefore, improvement in nebulizer technology and equipment design is crucial to increase the efficiency of aerosolized surfactant delivery.

\section{Internal factors of the newborn which may affect clinical response to aerosolized SRT}

Some internal factors (respiratory structure and physiology) have been identified by these trials to provide some explanation for failure and key points for improvement. Those factors were: pattern of lung injury, lung maturation, plasma protein leakage into the airspaces of the lung, physiology of surfactant inside the lung and newborn breathing physiology.

The nature of surfactant distribution using the aerosolized method follows the airway ventilation pattern. Normal, well-ventilated areas of the lung will achieve higher deposition of aerosolized surfactant. In non-uniform 
lung injury, the underventilated areas will receive less or no surfactant at all, and this determines the physiologic response to aerosolized SRT.(11, 26, 45-47) Henry, et al.(58) found a relationship between compliance of the lung and improvement in lung function. More compliant lungs are able to provide better ventilation and therefore distribution of aerosolized surfactant. Lung compliance is related to the degree of maturation of the lung, thus the gestational age.

Bahlamann, et al.(51) recovered human albumin protein from post-mortem bronchoalveolar lavage fluid to determine the human albumin concentration (as an indicator of pulmonary vascular-to-alveolar protein leakage). They found that there was a significant negative correlation between the amount of human albumin $(\mathrm{mg} / \mathrm{kg})$ in the lavage fluid and final values for $\mathrm{PaO}_{2}(\mathrm{r}=-0.67, p<005)$. This correlation was not shown in animals treated with instilled surfactant. It was concluded that the treatment effect depends on the quantity of surfactant delivered to the lung and the amount of plasma protein leakage to the same compartment. This did not occur in the instilled surfactant group because the large amount of surfactant counterbalanced the vascular-to-alveolar leak of surfactant inhibitors.(51) They also suggested that there was an underestimation in the aerosolized surfactant deposition analysis, because the surfactant materials quickly become lung-associated (cannot be recovered).(51) In addition, exogenous surfactant delivered as aerosol could stimulate endogenous surfactant production, which will sustain improvement of lung function over a period of time.(48-50)

\section{Discussion}

It is important to understand that it is difficult to effectively compare these trials due to variations in factors affecting the outcomes (e.g. initiation time of therapy, difference in baseline conditions, type of surfactant used and delivery method, diversity of species in animal trials, etc). Therefore, this discussion intends to consider evidence from individual human and animal trials and identify the significant issues and challenges regarding the use and future development of aerosolized SRT.

\section{Summary of trials in human newborns and animals}

There are discrepancies in the outcomes of aerosolized surfactant trials in humans. Three trials $(18,20,24)$ showed some benefit whereas the other two $(42,46)$ did not show any improvement in lung function. On the other hand, animal trials have shown that aerosolized surfactant is effective in treating RDS with only two trials $(54,58)$ reporting only minimal improvement in lung function. These trials have also provided insights into factors leading to successful treatment, and how to improve the aerosolized surfactant method.

\section{Factors which influence effectiveness of aerosolized SRT}

The improvement of lung function in human and animal trials varies broadly from no treatment $\operatorname{effect}(42,43,46)$ to a significant improvement comparable to the instillation method(41,51). This response appears to be independent of factors such as the diameter of surfactant particles generated, types of surfactant preparation used(70) and types of nebulizer used.

Factors increasing the response to aerosolized surfactant include: the baseline condition of the baby (poorer initial condition leads to a worse prognosis)(41,51), the stage of lung maturation (more mature lung provides better ventilation and thus better distribution of surfactant) $(39,42,58)$, the underlying pattern of lung injury (more effective in a uniform pattern of lung injury)(58), the initiation time of therapy (earlier initiation of treatment offers a better prognosis)(41), the total amount of surfactant used (more surfactant administered leads to better clinical response)(52), and the duration of inhalation (longer inhalation period allows for greater improvement in gas exchange)(52)

Modifications to the equipment such as delivering surfactant only during inspiration(58-60) or using low CPAP flow $(43,60)$ showed increased efficiency in the usage of surfactant materials and gave higher dose-effectiveness. Addition of compounds such as dextran(50) or using dried surfactant(55) was demonstrated to provide additional benefit in animal trials however, these methods are not yet tested in human trials.

\section{Advantages and disadvantages of aerosolized SRT}

Advantages of aerosolized SRT that have been confirmed in human and animal trials are: firstly, it has better dose effectiveness if calculated by the actual amount of surfactant that is deposited in the lung. $(50,51,60,61)$ Secondly, it is less invasive.(42) Thirdly, it produces less side effects such as no change in pulmonary blood flow(57) and no hypotension $(49,56)$ compared with instilled surfactant. Fourthly, it is distributed more uniformly in a uniform pattern of lung injury.(42, 57, 61) Fifthly, it can be delivered to moderately sick babies without the need of intubation(42,51), and finally, it can be given continuously without disconnecting from the ventilator(42, 51).

Disadvantages of aerosolized SRT as mentioned in these trials are: firstly, limited or negligible clinical effect. $(42,43,46,54,58)$ Secondly, it needs a long treatment period 
of three to six hours.(42,43,46,61) Thirdly, it utilizes a large volume of surfactant. $(41,52,54)$ Fourthly, it is less effective in treating non-uniform patterns of lung injury. (58-60) Fifthly, it has a slower initiation of clinical effect compared with instilled surfactant $(49,52,53,61)$, and finally, it increases pulmonary secretions(41).

\section{Challenges and future recommendations for aerosolized SRT}

In reality, mild or moderate RDS may improve with CPAP alone. A useful approach would be to investigate the use of aerosolized surfactant in sicker (intubated and ventilated) infants, a population which would benefit the most from the surfactant therapy. This would require investigation of the delivery of aerosolized surfactant via ETT. Before this stage can occur, it is crucial to investigate the nebulization and delivery process to provide a more efficient use of aerosolized surfactant as well as better distribution and deposition in the lung.

\section{Conclusion}

Since the discovery of aerosolized surfactant for the treatment of RDS, there has been considerable progress in investigating the feasibility and development of this method. Despite some success in animal trials, aerosolized surfactant is not currently proven to be effective in treating newborns with RDS. Improvements in aerosolized medication technology could be expected to turn this circumstance around. For now, an essential approach would be to investigate how to improve surfactant distribution and deposition in the lung, to compare ETT and CPAP methods of delivery, determine the appropriate dose, and establish the appropriate population to treat. All these questions should be best answered by randomised controlled trials.

\section{References}

1. Zuo YY, Veldhuizen RA, Neumann AW, Petersen NO, Possmayer F. Current perspectives in pulmonary surfactant-inhibition, enhancement and evaluation. Biochim Biophys Acta. 2008; 1778: 1947-77.

2. West JB. Respiratory physiology: the essentials. Philadelphia: Lippincott Williams \& Wilkins; 2005.

3. Cole FS, Nogee LM, Hamvas A. Defects in surfactant synthesis: clinical implications. Pediatr Clin North Am. 2006; 53: 911-27.

4. Stevens TP, Sinkin RA. Surfactant replacement therapy. Chest. 2007; 131: $1577-82$.

5. Gupta S, Donn S. Novel Approaches to Surfactant Administration. Crit Care Res Pract. 2012; 2012: 278483.

6. Lissauer T, Fanaroff AA. Neonatology at a glance. Malden,
Massachusetts: Blackwell Publishing; 2006.

7. Goldenberg RL, Culhane JF, Lams JD, Romero R. Epidemiology and causes of preterm birth. Lancet. 2008; 371: 75-84.

8. Slattery M, Morrison J. Preterm delivery. Lancet. 2002; 360: 1489-97.

9. Beck S, Wojdyla D, Say L, Betran A, Merialdi M, Requejo J, et al. The worldwide incidence of preterm birth: a systematic review of maternal mortality and morbidity. Bull World Health Organ. 2010; 88: 31-8.

10. Bayi berat lahir rendah. In: Pudjiadi A, Hegar B, Handryastuti S, Idris N, Gandaputra E, Harmoniati E, editors. Pedoman pelayanan medis Jakarta: Ikatan Dokter Anak Indonesia; 2009. p. 23-9.

11. Haram K, Mortensen J, Wollen A. Preterm delivery: an overview. Acta Obstet Gynecol Scand. 2003; 82: 687-704.

12. Lal MK, Sinha S. Surfactant respiratory therapy using Surfaxin/ sinapultide. Ther Adv Respir Dis. 2008; 2(5): 339-44.

13. Lorraine B W, Michael A M. The acute respiratory distress syndrome. N Engl J Med. 2000; 342(18): 1334-49.

14. Notter R. Lung surfactants. Basic science and clinical applications. New York: Marcel Dekker, Inc; 2000.

15. Sinha S, Gupta S, Donn S. Immediate respiratory management of the preterm infant. Semin Fetal Neonatal Med. 2008; 13: 24-9.

16. Agrons GA, Courtney SE, Stocker JT, Markowitz RI. Lung disease in premature neonates: radiologic-pathologic correlation. Radiographics. 2005; 25(4): 1047-73.

17. Ballard PL, Merrill JD, Truog WE, Godinez RI, Godinez MH, McDevitt $\mathrm{TM}$, et al. Surfactant function and composition in premature infants treated with inhaled nitric oxide. Pediatrics. 2007; 120: 346-53.

18. Avery ME, Mead J. Surface properties in relation to atelectasis and hyaline membrane disease. Am J Dis Child. 1959; 97: 517-23.

19. Merenstein GB, Gardner SL. Handbook of neonatal intensive careFourth edition St. Louis, Missouri: Mosby-Year Book, Inc; 1998.

20. Vavasseur C, Foran A, Murphy JF. Consensus statements on the borderlands of neonatal viability: from uncertainty to grey areas. Ir Med J. 2007; 100(8): 561-4.

21. Brumley GW, Hodson WA, Avery ME. Lung phospholipids and surface tension correlations in infants with and without hyaline membrane disease and in adults. Pediatrics. 1967; 40: 13-9.

22. Fujiwara T, Maeta H, Chida S, Morita T, Watabe Y, Abe T. Artificial surfactant therapy in hyaline-membrane disease. Lancet. 1980; 1 : 55-9.

23. Kobayashi T, Kataoka H, Ueda T, Murakami S, Takada Y, Kokubo M. Effects of surfactant supplement and end-expiratory pressure in lung-lavaged rabbits. J Appl Physiol Respir Environ Exerc Physiol. 1984; 57: 995-1001.

24. Berggren E, Lachmann B, Curstedt T, Grossmann G, Robertson B. Gas exchange and lung morphology after surfactant replacement in experimental adult respiratory distress syndrome induced by repeated lung lavage. Acta Anaesthesiol Scand. 1986; 30: 321-8.

25. Rey M, Segerer H, Kiessling C, Obladen M. Surfactant bolus instillation: effects of different doses on blood pressure and cerebral blood flow velocities. Biol Neonate. 1994; 66(1): 16-21.

26. Schipper JA, Mohammad GI, van Straaten HL, Koppe JG. The impact of surfactant replacement therapy on cerebral and systemic circulation and lung function. Eur J Pediatr. 1997; 156: 224-7.

27. Kendig JW, Ryan RM, Sinkin RA, Maniscalco WM, Notter RH, Guillet $\mathrm{R}$, et al. Comparison of two strategies for surfactant prophylaxis in very premature infants: a multicenter randomized trial. Pediatrics. 1998; 101(6): 1006-12.

28. Nuntnarumit P, Bada HS, Yang W, Korones SB. Cerebral blood flow velocity changes after bovine natural surfactant instillation. J Perinatol. 2000; 20(4): 240-3.

29. Halliday $H$. Recent clinical trials of surfactant treatment for neonates. Biol Neonate. 2006; 89: 323-9. 
30. Engle WA. Surfactant-replacement therapy for respiratory distress in the preterm and term neonate. Pediatrics. 2008; 121: 419-32.

31. Vidyasagar D, Velaphi S, Bhat V. Surfactant Replacement Therapy in Developing Countries. Neonatology. 2011; 99: 355 - 66.

32. Stevens TP, Blennow M, Myers EH, Soll R. Early surfactant administration with brief ventilation vs. selective surfactant and continued mechanical ventilation for preterm infants with or at risk for respiratory distress syndrome. Cochrane Database Syst Rev. 2007; (4): CD003063.

33. Halliday H. Surfactants: past, present and future. J Perinatol. 2008; 28 : S47-S56.

34. Lewis JF. In vivo studies of aerosolized exogenous surfactant. Aerosol Sci Technol. 1995; 22(4): 354-63.

35. Ware L, Matthay M. The acute respiratory distress syndrome. N Engl J Med. 2000; 342: 1334-49.

36. Lopez E, Gascoin G, Flamant C, Merhi M, Tourneux P, Baud O. Exogenous surfactant therapy in 2013: What is next? who, when and how should we treat newborns infants in the future? BMC Pediatr. 2013; 13: 165.

37. Espinosa FF, Kamm RD. Bolus dispersal through the lungs in surfactant replacement therapy. J Appl Physiol. 1999; 86(1): 391-410.

38. Pillow J, Micnocchieri S. Innovation in Surfactant Therapy II: Surfactant Administration by Aerosolization. Neonatology. 2012; 101: 337-44.

39. Femitha P, Joy R, Adhisivam B, Prasad K, Gane BD, Bhat V. Surfactant Replacement Therapy (SRT) in Respiratory Distress Syndrome (RDS). Curr Pediatr Res. 2012; 16(2): 134-6.

40. Ramanathan R. Surfactant therapy in preterm infants with respiratory distress syndrome and in near-term or term newborns with acute RDS. J Perinatol. 2006; 26: 51-6.

41. Jorch G, Hartl H, Roth B, Kribs A, Gortner L, Schaible T, et al. Surfactant aerosol treatment of respiratory distress syndrome in spontaneously breathing premature infants. Pediatr Pulmonol. 1997; 24: 222-4.

42. Arroe M, Pedersen-Bjergaard L, Albertsen P, Bode S, Greisen G, Jonsbo $\mathrm{F}$, et al. Inhalation of aerosolized surfactant (Exosurf(R)) to neonates treated with nasal continuous positive airway pressure. Prenatal Neonatal Med. 1998; 3: 346-52.

43. Finer NN, Merritt TA, Bernstein G. A multicenter pilot study of Aerosurf delivered via nasal continuous positive airway pressure (nCPAP) to prevent respiratory distress syndrome in preterm neonates. Pediatr Res. 2006; 59: PAS2006: 4840.138.

44. Gardenhire D. Rau's respiratory care phamacology Rau JL, editor. St. Louis, Mo: Mosby/Elsevier; 2008.

45. Smedsaas-Löfvenberg A, Nilsson K, Moa G, Axelsson I. Nebulization of drugs in a nasal CPAP system. Acta Paediatr. 1999; 88: 89-92.

46. Berggren E, Liljedahl M, Winbladh B, Andreasson B, Curstedt T, Robertson B, et al. Pilot study of nebulized surfactant therapy for neonatal respiratory distress syndrome. Acta Paediatr. 2000; 89: 460-4.

47. Mathai SCS, Raju CU, Kanitkar M. Management of respiratory distress in the newborn. Med J Armed Forces India. 2007; 63: 269-72.

48. Finer N, Merritt T, Bernstein G, Job L, Mazela J, Segal R. An open label, pilot study of Aerosurf (R) Combined with nCPAP to prevent RDS in preterm neonates. J Aerosol Med Pulm Drug Deliv. 2010; 5: 303-9.

49. Tashiro K, Yamada K, Li W, Matsumoto Y, Kobayashi T. Aerosolized and instilled surfactant therapies for acute lung injury caused by intratracheal endotoxin in rats. Crit Care Med. 1996; 24: 488-94.

50. Cui X, Tashiro K, Matsumoto H, Tsubokawa Y, Kobayashi T. Aerosolized surfactant and dextran for experimental acute respiratory distress syndrome caused by acidified milk in rats. Acta Anaesthesiol Scand. 2003; 47: 853-60.

51. Bahlmann H, Sun B, Nilsson G, Curstedt T, Robertson B. Aerosolized surfactant in lung-lavaged adult rats: factors influencing the therapeutic response. Acta Anaesthesiol Scand. 2000; 44: 612-22.

52. Tashiro K, Yamada K, Konzaki T, Yamamoto K, Ohmura S, Kobayashi $\mathrm{T}$, et al. Aerosolized surfactant therapy for endotoxin-induced experimental acute respiratory distress syndrome in rats. $\mathrm{Br} \mathrm{J}$ Anaesth. 2001; 87(2): 266-71.

53. Li W, Chen W, Kobayashi T. Aerosolized surfactant reverses respiratory failure in lung-lavaged rats. Acta Anaesthesiol Scand. 1994; 38: 828.

54. Fok TF, Al-Essa M, Dolovich M, Rasid F, Kirpalani H. Nebulisation of surfactants in an animal model of neonatal respiratory distress. Arch Dis Child Fetal Neonatal Ed. 1998; 78(F): F3-F9.

55. Ellyett KM, Broadbent RS, Fawcett ER, Campbell AJ. Surfactant aerosol treatment of respiratory distress for spontaneously breathing premature rabbit. Pediatr Res. 1996; 39: 953-7.

56. Dijk PH, Heikamp A, Bambang Oetomo S. Surfactant nebulisation prevents the adverse effects of surfactant therapy on blood pressure and cerebral blood flow in rabbits with severe respiratory failure. Intensive Care Med. 1997; 23: 1077-81.

57. Lewis JF, Ikegami M, Jobe A, Tabor B. Aerosolized surfactant treatment of preterm lambs. J Appl Physiol. 1991; 70: 869-76.

58. Henry MD, Rebello CM, Ikegami M, Jobe AH, Langenback EG, Davis JM. Ultrasonic nebulized in comparison with instilled surfactant treatment of preterm lambs. Am J Respir Crit Care Med. 1996; 154: 366-75.

59. Lewis JF, Ikegami M, Jobe AH, Absolom D. Physiologic responses and distribution of aerosolized surfactant (Survanta) in a nonuniform pattern of lung injury. Am Rev Respir Dis. 1993; 147: 1364-70.

60. Lewis JF, McCaig L. Aerosolized versus instilled exogenous surfactant in a nonuniform pattern of lung injury. Am Rev Respir Dis. 1993; 148: $1187-93$.

61. Lewis JF, Tabor B, Ikegami M, Jobe AH, Joseph M, Absolom D. Lung function and surfactant distribution in saline-lavaged sheep given instilled vs. nebulized surfactant. J Appl Physiol. 1993; 74(3): 125664.

62. Rau JL. Design principles of liquid nebulization devices currently in use. Respir Care. 2002; 47(1): 1257-75.

63. Asmus MJ, Milavetz G, Tice AL, Teresi ME. In vitro characteristics of tobramycin aerosol from ultrasonic and jet nebulizers. Pharmacotherapy. 2001; 21(5): 534-9.

64. Rau JL. Design principles of liquid nebulization devices currently in use. Respir Care. 2002; 47(11): 1257-75.

65. Steckel H, Eskandar F. Factors affecting aerosol performance during nebulization with jet and ultrasonic nebulizers. Eur J Pharm Sci. 2003; 19(5): 443-55.

66. Adjei AL, Altiere RJ, Amin H, Asgharian B, Bernstein JA, Bhat M, et al. Inhalation aerosols: physical and biological basis of therapy second ed. Hickey A, editor. New York: Informa Healthcare; 2007.

67. Dolovich MA. Influence of inspiratory flow rate, particle size, and airway caliber on aerosolized drug delivery to the lung. Respir Care. 2000; 45(6): 597-608.

68. Ma CC, Ma S. The Role of Surfactant in Respiratory Distress Syndrome. Open Respir Med J. 2012; 6: 44-53.

69. Fuller H, Dolovich M, Chambers C, Newhouse M. Aerosol delivery during mechanical ventilation: a predictive in-vitro lung model. J Aerosol Med. 1992; 5: 251.

70. Holm BA. Editorial: Surfactant replacement therapy, new level of understanding. Am Rev Respir Dis. 1993; 148: 834-6. 